Izvorni članak UDK 1:2-22(045)

1 Schelling, F. W. J.

doi: $10.21464 /$ fi40102

Primljeno 3. 10. 2019.

\title{
Stjepan Kušar
}

Hrvatsko katoličko sveučilište, Ilica 242, HR-10000 Zagreb

stjepan.kusar@unicath.hr

\section{Objava u filozofiji?}

\section{Uvid u Schellingov pojam objave}

\begin{abstract}
Sažetak
U članku se daje ocrt Schellingova poimanje objave; ono nije svedeno na teološki shvaćen pojam objave, nego ga pokazuje u širini autorove filozofske misli, od njegovih filozofskih početaka preko filozofije slobode pa do pozitivne filozofije. Pojam objave pokazuje se u svojoj tijesnoj povezanosti s poimanjem slobode - Božje i čovječje - i s mogućnošću i potrebom da se promišlja umu onostrani Apsolut a da nije »ukonačen " $u$ imanenciju uma $i$ njegova umovanja. Objava je shvaćena kao slobodna povijesna manifestacija Apsoluta, ponuda $i$ apel čovječjoj slobodi i čovjekovu djelovanju u povijesti; ona je također moment života Boga koji sam ispostavlja stvorenje i ide mu ususret te ga vodi k cilju: da on, Bog, bude sve u svemu.
\end{abstract}

\section{Ključne riječi}

Friedrich Wilhelm Joseph Schelling, objava, religija, sloboda, Apsolut, negativna filozofija, pozitivna filozofija, Bog, Krist

Pokušaj uvida u poimanje objave u kontekstu Schellingove filozofije zahtijeva prouku cjeline njegovih tekstova, što u okviru jednog članka nije izvedivo. No moguće je istaknuti neke važne momente tog pojma u cjelini njegova opusa. Schellingovo filozofsko stvaralaštvo dade se ugrubo sagledati u tri periode koje su uzajamno povezane; uza sve ne male razlike one pokazuju kretanje misli pri čemu se bitni prethodni uvidi ne brišu, nego ulaze u nove kontekste promišljanja. Stoga ima smisla njegovu misao prema $X$. Tilliettu nazvati »filozofijom u nastajanju «. ${ }^{1}$ Riječ je najprije o ranoj periodi koja započinje $\mathrm{s}$ raspravama o Fichteovu subjektivnom idealizmu, nastavlja se u filozofiji prirode i završava u filozofiji identiteta; potom srednja perioda koja započinje spisom o slobodi (1809.) te se dalje izgrađuje u prvom redu filozofijom razdoblja svijeta (Weltalter); na nju se nadovezuje završna perioda (pozni Schel-

1

Usp. Xavier Tilliette, Schelling. Une philosophie en devenir, 2. sv., J. Vrin, Paris 1970. Za prvu informaciju o Schellingu usp. Damir Barbarić, »Friedrich Wilhelm Joseph Schelling «, u: Damir Barbarić (ur.), Hrestomatija filozofije: Filozofija njemačkog idealizma, sv. 6, Školska knjiga, Zagreb 1998.; Damir Barbarić, natuknica »Schelling, Friedrich Wilhelm Joseph«, u: Stipe Kutleša (ur.), Fi- lozofski leksikon, Leksikografski zavod »Miroslav Krleža«, Zagreb 2012. U povodu 150. obljetnice Schellingove smrti objavljena je u Njemačkoj opsežna Schellingova biografija iz pera jednog od najboljih poznavatelja njegova života i njegove misli: Xavier Tilliette, Schelling. Biographie, J. G. Cotta, Stuttgart 2004. (franc. original 1999.). 
ling) kojoj je u središtu pozornosti filozofija mitologije i filozofija objave, od druge polovice 1820 -ih godina pa do smrti $1854 .^{2}$

Pritom se uvijek iznova javljaju razne teme (duh, priroda, identitet, sloboda itd.) od kojih je jedna također objava (Offenbarung). Pojam je prisutan od početka, što ne čudi ako se ima u vidu da je Schelling po formaciji teolog; sama tematika objave Apsoluta (filozofsko ime za Boga) postupno biva sve izrazitije prisutnom i obrađivanom počam od spisa o slobodi, da bi na kraju u pozitivnoj filozofiji zauzela središnje mjesto o čemu svjedoči niz predavanja naslovljenih Filozofija objave od konca 1820-ih godina do smrti. Uz filozofiju objave ide filozofija mitologije; obje zajedno tvore pozitivnu filozofiju koja je tijesno povezana s negativnom filozofijom. I jednoj i drugoj u središtu je pozornosti pitanje o Apsolutu i pristup k njemu - i obrnuto: manifestacije Apsoluta. Dok je on u negativnoj filozofiji tek »dodirnut « kao mogućnost za spekulativni um, pozitivna filozofija polazi od Apsoluta kao danosti i od njegova sebeotkrivenja u religijskoj povijesti čovječanstva s kulminacijom u kršćanskoj objavi.

Stoga nam se čini umjesnim upozoriti na mjesto objave u Schellingovu opusu te istaknuti njezinu važnost i filozofski interes za nju - što baš i ne izgleda kao sama po sebi razumljiva stvar ako imamo u vidu porijeklo tog pojma u kontekstu kršćanske teologije. ${ }^{3}$ Schelling raspravlja o tome upravo u svojoj filozofiji objave. Ona treba pokazati da »objava nije neki nužni proizvod, nego je manifestacija najslobodnije volje božanstva; ovdje dopiremo do krajnje linije gdje nikad i nipošto nemamo posla s nužnošću nego sa slobodnom odlukom «. ${ }^{4} \mathrm{U}$ ovome što slijedi ističemo neke važne dionice autorova puta do tog cilja.

\section{I.}

Mladi Schelling (1794. - 1809.) najprije je pod snažnim utjecajem »Fichteova subjektivnog idealizma s njegovim ishodištem u produktivnoj djelatnosti jastva kao transcendentalnog zrenja«. Fichte je tražio takvu znanost koja bi proizlazila samo iz jednog principa pa bi kao takva bila apsolutno jedinstvo subjekta i objekta. On je to jedinstvo nalazio u »Ja« subjekta (das Ich, jastvo kao transcendentalno zrenje), tj. samo u subjektivnoj znanosti, ali ne i u onome što je znano. Za Schellinga se pak jedinstvo onog subjektivnog i onog objektivnog ne nalazi samo u subjektu znanja nego i u objektu znanja - to je priroda. Stoga Schelling postavlja filozofiju prirode, koja je u reciprocitetu s transcendentalnom filozofijom subjekta te joj je utoliko komplementarna. Kao što je, dakle, Fichteova transcendentalna filozofija izlagala dedukciju svega znanog iz dijalektike kategorija u transcendentalnom jastvu, tako sada Schelling u svojoj filozofiji prirode želi izložiti povijest razvitka onog znanog (prirode) i to tako da polazeći od njega dopre sve do subjekta znanja. Tu »dihotomiju filozofije prirode i transcendentalne filozofije, zajedno s njihovim osnovnim načelima, produktivnošću prirode $s$ jedne i spontanošću jastva $s$ druge strane, razrađenu u dvjema ranijim fazama « Schelling kani prevladati ili bolje »ukinuti u jednom jedinom najvišem principu«; tako on izgrađuje filozofiju identiteta u kojoj poima sam Apsolut kao nediferencirani identitet subjektiviteta i objektiviteta. On se poima u intelektualnoj ili umskoj intuiciji; ona je svojevrsna točka u kojoj su jedno te isto znanje o Apsolutu i sam Apsolut. ${ }^{5}$

U tom je kontekstu smisao pojma objave dvostruk: s jedne strane, i na liniji Fichteove misli ona ističe zadaću filozofije - objaviti čovjeku njegovu slo- 
bodu kao apsolutnost koja se pokazuje u svojoj spontanosti i neizvedivosti iz nekih prethodno danih uvjeta. Za to filozofiji nije potrebna religijska objava, ali je ona potrebna utoliko što jača religiozni osjećaj u čovjeku, a religija ga vodi k moralu i učvršćuje mu moral. ${ }^{6}$ Objava je važan pedagoški moment jer raspoložuje čovjeka za moralnost i odgaja mu moralni osjećaj. Objava dakle znači manifestaciju apsolutnosti slobode i čovjekove moralnosti koju učvršćuje religijski moment objave.

Ne kanimo ulaziti u prikaze i prijepore unutrašnje periodizacije Schellingove misli; usp. uz X. Tilliettea također Walter Schulz, Die Vollendung des deutschen Idealismus in der Spätphilosophie Schellings, drugo prošireno izdanje, Günther Neske, Pfullingen 1975. (1955, 1. izd.); Horst Fuhrmans, »Die Philosophie der Weltalter«, Studia Philosophica 14 (1954), str. 2-17; Christian Iber, Das Andere der Vernunft als ihr Prinzip. Grundzüge der philosophischen Entwicklung Schellings mit einem Ausblick auf die nachidealistischen Philosophiekonzeptionen Heideggers und Adornos, De Gruyter, Berlin 1994. Za uvod u Schellingovu filozofiju usp. Hans Michael Baumgartner; Harald Korten, Friedrich Wilhelm Joseph Schelling, C. H. Beck, München 1996.

U Novom zavjetu dva su markantna mjesta na kojima se susrećemo s pojmom objave; riječ je o »objavljenju Otajstva (gr. mystérion) prešućenog drevnim vremenima, a sada očitovanog i po proročkim pismima odredbom vječnog Boga svim narodima obznanjenog za poslušnost, vjeru « (na kraju poslanice Rimljanima 16,25-26). Slično i na početku poslanice Hebrejima, s tom razlikom da je naglasak pomaknut na Božji govor ljudima: »Više puta i na više načina Bog nekoć govoraše ocima po prorocima; konačno, u ove dane, progovori nama u Sinu«, tj. u Isusu Kristu koji je »baštinik svega i po kome sazda svjetove (1,1-2). Usp. detaljnije natuknicu »Objava« u: Xavier Léon-Dufour (ur.), Rječnik biblijske teologije, preveo Mate Križman, Kršćanska sadašnjost, Zagreb 1969., te u: Luciano Pacomio, Vito Mancuso, Alfonso Ortiz García (ur.), Enciklopedijski teološki rječnik, Aldo Starić (ur. hrvatskog izdanja), preveli Slavko Antunović i dr., Kršćanska sadašnjost, Zagreb 2009. U Tome Akvinskog termin ima svoje čvrsto mjesto te izražava bitnu razliku između filozofskog i teološkog poimanja Boga, usp. Sth I,1,1 cp. art.

Tako piše u najranijoj cjelovitoj verziji filozofije objave čiji je rukopis objavljen 1992 pod naslovom Friedrich Wilhelm Joseph Schelling, Urfassung der Philosophie der Offenbarung, Walter E. Ehrhardt (ur.), 2. sv., Felix Meiner, Hamburg 1992.; skraćenica: UphO, str. 409. Riječ je o tekstu predavanja održanih u Münchenu 1831./1832. U napo- menama smo na nekim mjestima upozorili na paralelna mjesta tog spisa sa svescima iz Schellingovih Sveukupnih djela čije je izdanje priredio njegov sin (SW XIII i XIV: berlinska predavanja 1841./1842.; usp. nap. 5); za sada nema još neke studije koja bi sustavno usporedila obje verzije. Usprkos razlikama, pogotovo u prvom svesku obaju izdanja (uvodni dio u SW XIII, 1-173 kojeg nema u UphO te predavanja o monoteizmu u UphO 101-118 koja nemaju paralelu u SW XIII), X. Tilliette u svojoj recenziji UphO (Archives de philosophie 57 (1994) 4, str. 706-709) smatra da ta publikacija neće u bitnom promijeniti sliku o autoru i njegovoj poznoj misli.

Citati su preuzeti iz članka Damira Barbarića u Filozofskom leksikonu (usp. nap. 1); usp. SW I, 318 (= Philosophische Briefe über Dogmatismus und Kritizismus). Schellingova djela navodimo prema izdanju koje je pripremio njegov sin: Friedrich Wilhelm Joseph Schelling, Sämtliche Werke, Karl Friedrich August Schelling (ur.), J. G. Cotta, Stuttgart, Augsburg 1856.; reprografsko izdanje Darmstadt 1974. Skraćenica: SW, broj sveska, broj stranice.

6

Ovdje je zasigurno na djelu prosvjetiteljsko shvaćanje kršćanstva (Lessing) kao odgajatelja čovječanstva odnosno Kantovo poimanje objavljene religije: ona je spoznaja naših moralnih dužnosti kao Božjih zapovijedi; usp. Stjepan Kušar, »Filozof, religija i radikalno zlo. Marginalije uz Kantovu filozofiju religije«, u: Ozren Žunec, Petar Šegedin (ur.), Zbližavanja. Zbornik povodom šezdesete obljetnice života Damira Barbarića, Matica hrvatska, Zagreb 2012., str. 132-138, str. 127. Za Gottholda Ephraima Lessinga usp. Gotthold Ephraim Lessings, Die Erziehung des Menschengeschlechts, Reclam, Stuttgart 1965., $\S \S 1$ i 76. Kasnije, u svojem spisu o slobodi (usp. nap. 18), Schelling izričito priznaje svoju povezanost s Lessingom (85/64, SW VII, 412); zajedno s njim on zahtijeva izobrazbu objavljenih istina $\mathrm{u}$ istine uma kao nužnost ako bi se time trebalo pomoći čovječanstvu. Istine morala u objavi su nadohvat ruke. Kasnije međutim, on otklanja prosvjetiteljsko shvaćanje objave ističući da uz um valja uzeti (šire negoli u Kanta shvaćeno) iskustvo kao izvor spoznaje: »Mnogo je toga što znamo a posteriori, a ne a priori.«-UphO, 404. 
Kasnije međutim, u svojoj kritici Spinozina dogmatizma, Schellingu se nameće potreba progovoriti o objavi na drukčiji način, naime: je li moguć objektivni odnos između konačnog i beskonačnog odnosno ima li uopće smisla neki apsolutni objekt (Bog) za konačnog čovjeka? Drugim riječima, je li moguća objava Boga u povijesti? Čini se da nije jer Bog kao apsolutni ili totalni objekt izmiče iskustvu konačnog čovjeka, njegova objava značila bi ukidanje povijesti. ${ }^{7}$ Preostaje samo to da ga se shvati kao krajnji horizont konačne slobode odnosno kao apsolutnu slobodu koja uvjetuje čovječju empirijsku slobodu u njezinu ozbiljenju kroz moralno djelovanje. Bog je dakle horizont naših sloboda, on ima smisla za nas ljude polazeći od našeg moralnog iskustva, tj. od iskustva mnoštva subjekata koji su angažirani u zajedničkom iskustvu življenja. U tom smislu bi se objava Božja mogla misliti kao obećanje moralne budućnosti čovječanstva koje je u svojem povijesnom hodu prema Bogu; Bog bi bio Budućnik. ${ }^{8}$

No kako u filozofiji identiteta u igru ulazi također priroda, Apsolut se ovdje javlja kao živi princip koji prožima svu prirodu i sve u prirodi, a da se pritom ni u čemu ne iscrpljuje; on je priroda koja samu sebe pri-rađa (natura naturans), a udes je čovječjeg slobodnog duha da osvijesti tu ne-svjesnu prošlost u kojoj su mu korijeni. ${ }^{9}$ Problem Apsoluta ili Boga se dakle ne svodi na moralni udes slobodnih ljudi, on je posvuda, u nama i izvan nas, u prirodi. To drugim riječima znači da je njegovo očitovanje ili objava »koekstenzivna s poviješću i istovremena s formama prirode« pa svijet i čovjek nalaze svoj smisao u Bogu. Stoga valja krenuti od »afirmacije Boga u prirodi i u povijesti« i uvidjeti da on u njima i kroz njih objavljuje samoga sebe. ${ }^{10}$ Riječ je, dakle, o samoobjavi Božjoj u kojoj on ujedno afirmira samoga sebe i afirmiran je kroz prirodu i povijest. S obzirom na to Schelling diferencira stari svijet na čijoj je granici kršćanstvo i njegov središnji lik Isus Krist i novi svijet duha koji je u nadolasku. Pritom je stari ili pretkršćanski svijet »prirodna strana povijesti« utoliko što je, ističe Schelling već 1802. u svojim predavanjima $O$ metodi akademskog studija:

»... jedinstvo koje u njemu vlada ili ideja bitak onog beskonačnog u konačnome. Završetak starog vremena i granica jednog novog, kojega je vladajući princip bilo ono beskonačno, mogao je biti samo tako načinjen da je ono istinski beskonačno došlo u ono konačno, ne da bi ovo obožanstvenilo, nego da bi ga u svojoj vlastitoj osobi žrtvovalo Bogu i time pomirilo. Prva ideja kršćanstva je otuda nužno čovjekom postali Bog, Krist kao vrhunac i kraj starog svijeta bogova (...). $\ll^{11}$

To je vrhunska forma Božje objave u povijesti, ali - dobro luteranski - sub contrario, pod onim suprotnim i to stoga što Krist

»... u sebi čini konačnim ono božansko, ali on ne poprima čovještvo u njegovoj uzvišenosti, nego u njegovoj niskosti, i stoji tu kao od vječnosti doduše završena, ali u vremenu prolazna pojava, kao granica obaju svjetova; on sam vraća se u nevidljivo, i umjesto sebe ne obećava princip koji će doći u konačno, u konačnosti ostati, nego obećava duh, idealni princip, koji naprotiv ono konačno vodi natrag k beskonačnom i kao takav jest svjetlo novog svijeta. « ${ }^{12}$

U tom kontekstu objava signalizira prijelaz prema novoj religiji duha u kojoj će priroda biti preobražena slobodom, a sloboda će steći neposredan odnos prema samoj sebi upravo u formama prirode i povijesti (posredovana neposrednost). Središnja figura objave je Krist.

Za Schellinga se to oprimjeruje u svijetu umjetnosti; ona predstavlja izvrsnu i definitivnu formu pomirenja prirode i povijesti te je ona "posve apsolutna, savršena u-jedno-uobrazba onog realnog i idealnog $\ll .{ }^{13} \mathrm{U}$ umjetničkoj djelatnosti naime nalazi se identitet znanja i djelovanja, svjesnog i ne-svjesnog proizvođenja, organizma i razuma. Pritom umjetnik nije svoj gospodar, nego je 
kao genij (Genie) instrument Boga koji objektivira svoje ideje u umjetničkom stvaralaštvu čovjeka-umjetnika; ovaj djeluje nužno jer je pod nadahnućem ili inspiracijom odozgo. Umjetničko djelo izlaže u ljudskom svijetu (povijest) forme stvari kakve su u sebi ili u Apsolutu, što znači da ih izlaže kao istodobno realne i idealne. ${ }^{14}$ Puno poimanje toga vlastito je filozofiji koja poima ono idealno dok je umjetnost na strani onog realnog što međutim ne ukida njihovu povezanost; ona je neukidiva:

»Ukoliko je ono idealno uvijek neki viši refleks onog realnog, utoliko je u filozofu nužno još i neki viši idealni refleks onoga što je u umjetniku realno. «15

Ipak, umjetničko djelo nije najviši oblik dosizanja Apsoluta jer ono izražava samo ne-diferenciju (Indifferenz) realiteta i idealiteta, subjektiviteta i objektiviteta, ali još ne izražava njihov identitet; taj se može pojmiti samo umom u filozofiji. Stoga Schellingova filozofija identiteta nadilazi ne samo dualitet prirode i jastva i objave Apsoluta u njihovoj napetosti nego i ne-diferenciju idealnog i realnog i objave Apsoluta u umjetnosti te se uspostavlja kao poimanje Apsoluta u samome sebi i to snagom uma koji je savršena slika Božja u univerzumu. Um, naime, djeluje snagom načela identiteta i u skladu s njime pa u svojem umovanju ukida diferenciju subjektiviteta i objektiviteta te poima sam Apsolut kao nediferencirani identitet subjektiviteta i objektiviteta odnosno kao totalitet bez dijelova. Njegova se bit izražava (objavljuje) u beskonačnoj igri ideja ili formi koje se međusobno razlikuju samo prema kvaliteti, tj. prema izražajnosti apsolutne biti u njima. Um to poima u svojoj umskoj intuiciji. Odatle filozofirati znači prepustiti se toj samospoznaji Apsoluta u umskoj intuiciji - ona je točka u kojoj su jedno te isto i znanje o Apsolutu i sam Apsolut, kako je to Schelling izrazio već u Prikazu svog sistema filozofije:

»U svima nama prisutna je neka tajna i čudesna sposobnost povlačenja samih sebe iz promjenjivosti vremena u naše najunutarnjije i svih vanjskih akcidenata lišeno sebstvo tako da u njemu intuiramo pod vidikom nepromjenjivosti ono samo Vječno u nama. «16

Ostaje međutim problem: koji su razlozi spomenute nužne autodiferencijacije nediferenciranog identiteta Apsoluta koji eksplicira samog sebe u svijet ideja odnosno formi? Kako i zašto se one realiziraju u zbilji prirode i u povijesti?

Usp. SW I, 294 (= Philosophische Briefe über Dogmatismus und Kritizismus); SW III, 328 i d. (= System des transzendentalen Idealismus).

8

Usp. SW III, 604.

Usp. SW III, 284-300.

10

Marc Maesschalck, »Philosophie et révélation chez Schelling «, Revue Théologique de Louvain 20 (1989) 3, str. 281-307, str. 297, doi: https://doi.org/10.3406/thlou.1989.2382; usp. SW III, 284, 299 i d.

11

SW V, 292; hrv. prijevod: Friedrich Wilhelm Joseph Schelling, »O metodi akademijskog studija « u: Ideja univerziteta.Kant-Schelling - Nietzsche, preveo Branko Despot, Globus, Zagreb 1991., str. 123-241, str. 191-192.
12

Ibid.; hrv. prijevod: str. 192.

13

Ibid. str. 348; hrv. prijevod: str. 238.

14

Usp. pobliže SW V, 357-370, napose 368 (= Philosophie der Kunst, § 24).

15

F. W. J. Schelling, »O metodi akademijskog studija «, str. 238 (nap. 11).

16

SW I, 318 (= Philosophische Briefe über Dogmatismus und Kritizismus). Ili lapidarno u formi aforizma: »Um nema ideju Boga, nego on jest ta ideja i ništa drugo.« - SW VII, 149 (= Aphorismen zur Einleitung in die Naturphilosophie). 
Drugim riječima, treba riješiti problem stvaranja. No prije negoli kušamo pokazati smjer odgovora u drugoj periodi Schellingova stvaralaštva, istaknimo »dobitak « u pogledu pojma objave. On se pokazuje u svojoj značajnosti za filozofiju i za njezinu zadaću ne samo ukoliko je riječ o objavi apsolutnosti čovjekove slobode nego i o samoobjavi Boga u realitetu i idealitetu u kojima se on afirmira i u kojima je on afirmiran ujedno:

»Nema neke više objave niti u znanosti i religiji niti u filozofiji od objave božanstvenosti svega: štoviše, znanost i religija polaze samo od te objave i imaju smisla samo po njoj.«17

S obzirom na ovo primarno značenje od sekundarnog je značenja objava u Kristu: osim što ostaje prosvjetiteljski intoniran smisao religije i njezine objave kao sredstva koje disponira čovjeka za moralnost i učvršćuje ga u njoj, objava u Kristu pokazuje ovoga u njegovu prijelaznom značenju - u povijesti on otvara prijelaz prema novom svijetu, prema budućoj religiji duha u kojoj će Bog biti sve u svemu (1 Kor 15,28). ${ }^{18}$ Time je pojmu objave doznačeno njezino mjesto u kontekstu filozofije; ona kroz misleći um izražava manifestaciju Apsoluta, Jednoga i Svega, u prirodi i u povijesti.

\section{II.}

Schelling postavlja u svojoj filozofiji slobode gore spomenuti problem na najzaoštreniji način utoliko što u svojim Istraživanjima o bitstvu čovječje slobode definira ljudsku slobodu kao »sposobnost zla i dobra ${ }^{19}$ nadilazeći tako Kantov i Fichteov pojam slobode kao intelektualnog spontaniteta, ali i Hegelov pojam slobode kao adekvacije (subjekta-čovjeka) sa samim sobom.

Odatle je pak potrebno istražiti i filozofski utemeljiti pozitivnu mogućnost zla. Taj temelj zla ne može se tražiti u Bogu, smatra Schelling, jer Bog tako ne bi bio najsavršeniji. No on se također ne može tražiti ni u nekom radikalnom dualizmu jer na taj način ne bismo imali nikakve prave spoznatljivosti stvarnosti. ${ }^{20}$

Schelling nalazi princip rješenja u daljnjem razvitku temeljne intuicije svoje filozofije, tj. u nužnosti da prihvati uz idealizam svjesnog jastva također realizam nesvjesne prirode kao isto tako originaran ili izvoran kao što je i idealizam jastva. U filozofiji identiteta, naime, bit je Apsoluta u samoj sebi nedokučiva umu; no ona se eksteriorizira u formama prirode i povijesti. Odatle onda opozicija bîti i formā. Sada pak, u spisu o slobodi, Schelling uvodi opoziciju u sam Apsolut u kojem razlikuje temelj (Grund) i egzistenciju. Pritom se on poziva na svoju raniju filozofiju prirode koja je »postavila u znanosti razlikovanje između bitstva (Wesen), ukoliko ono egzistira, i bitstva, ukoliko je ono puki temelj egzistencije . $^{21}$

Temelj je ono po naravi prethodeće aktualnoj egzistenciji; on je prema ovoj usmjeren i tim usmjerenjem njome uvjetovan - kao što je i ona, obrnuto, uvjetovana njime. Potrebno je jasno imati pred očima narav tog uzajamnog prethođenja. Ono se ne smije misliti

»... niti kao prethođenje po vremenu, niti kao prioritet bitstva. U krugu iz kojega sve biva nije nikakvo proturječje, da ono kroz što se jedno proizvodi, sâmo bude opet proizvedeno od njega. Ovdje nikoje nije Prvo i nikoje nije Posljednje jer se sve uzajamno pretpostavlja, nikoje nije drugo, a ipak nije bez drugoga.«

S obzirom na Boga to znači:

»Bog ima u sebi unutrašnji temelj svoje egzistencije, koji utoliko prethodi njemu kao egzistirajućem; ali isto je tako Bog prius temelja time što temelj, također kao takav, ne bi mogao biti 
kada Bog ne bi actu egzisitirao (...). Ushtjednemo li si mi ovo bitstvo ljudski približiti, možemo kazati: ono je čežnja (die Sehnsucht) koju vječno Jedno osjeća da sebe sama rodi. Ona nije ono Jedno sámo, ali je ipak s njime jednako vječna. Ona hoće roditi Boga, to znači nedokučivo jedinstvo, ali utoliko u njoj samoj još nije jedinstvo. $\ll^{22}$

Bog koji actu (zbiljski) egzistira kao svjestan i osoban ima tu bitnu vlastitost da se vraća k samome sebi i re-flektira sebe u sebi: samoga sebe predočuje u Umu ili Riječi (Logos). Ta pak umujuća Riječ, jer ne može biti odijeljena od originarne čežnje, po toj istovjetnosti s čežnjom tvori racionalnu volju koja je slobodna i osobna, tj. ona je tako Duh ili Ljubav.

Daljnje će dakle djelovanje Božje stoga nužno biti slobodno i osobno stvaranje koje proistječe iz ljubavi.

»Shodno čežnji, koja je kao još mračni temelj prvo gibanje božanskog opstanka, proizvodi se u Bogu samome jedna unutrašnja refleksivna predstava, kroz koju, budući da ona ne može imati nikakav drugi predmet osim Boga, Bog sagledava sebe sama u vlastitoj slici. Ova predstava je ono prvo u čemu je Bog, apsolutno promatran, ozbiljen, iako samo u sebi samome; ona je u početku kod Boga, i $u$ Bogu proizvedeni Bog sam. Ova predstava je ujedno razum - Riječ (smisao) one čežnje, i vječni duh, koji osjeća Riječ u sebi i ujedno beskonačnu čežnju, pokrenut od ljubavi, koja jest on sam, izgovara Riječ, da sad sam razum zajedno sa čežnjom bude slobodnostvarajuća i svemoćna volja i da u prvobitno bespravilnoj prirodi obrazuje kao u svome elementu ili oruđu. $\ll^{23}$

Tu se dakle ona opozicija temelja i egzistencije u Bogu »prevodi « u opoziciju voljā u Bogu: imamo slijepu volju temelja i svjetlu volju umstvenosti. Ta je opozicija dinamična i izvor je života u Bogu - po njoj je on živi Bog.

Taj teogonijski proces ujedno je samoobjavljivanje Boga samome sebi. Bog je Bog kao čista autokomunikacija samoga sebe samome sebi, u sebi jasan i razgovijetan - slobodan manifestirati se također onome koje kao moguće postojeće tek treba biti. U samome Bogu naime oduvijek je otvorena mogućnost stvaranja ne-Boga kao onoga kojemu se on, ushtjedne li, bude mogao objaviti. Tako se ujedno otvara perspektiva stvaranja kao općenitog objavljivanja Boga samim činom stvaranja, ali i perspektiva posebnog objavljivanja Boga slobodnom čovjeku u krilu stvorenja.

Stvorenje čiji je prototip čovjek kao savršeno stvorenje postaje u ne-Bogu i iz ne-Boga, tj. iz Božjeg temelja, ukoliko se naime ovome iz stvaralačke Božje

17

SW VII, 140 (= Aus den Jahrbüchern der Medicin als Wissenschaft).

18

Što odatle slijedi za teologiju o tome se Schelling izjasnio u svojim predavanjima o metodi akademskog studija, usp. nap. 11 (str. 187202).

19

Schellingov spis o slobodi navodimo prema izdanju koje je uredio Thomas Buchheim: Friedrich Wilhelm Joseph Schelling, Philosophische Untersuchungen über das Wesen der menschlichen Freiheit und die damit zusammenhängende Gegenstände, Felix Meiner, Hamburg 1997., te prema hrvatskom prijevodu: Friedrich Wilhelm Joseph Schelling, »Filozofijska istraživanja o bitstvu čovječje slobode i predmetima koji su s time u svezi«, u: Friedrich Wilhelm Joseph Schelling, $O$ bitstvu slobode, preveo Branko Despot, Cekade, Zagreb 1985., str. 13-67; dodajemo također svezak i stranice prema prvom izdanju Schellingovih sabranih djela, str. 25-27; SW VII, 352. Uz cijeli ovaj odsjek usp. Stjepan Kušar, »Stvaranje i objava«, u: Damir Barbarić (ur.), Sloboda i zlo. Schellingov »Spis o slobodi«, Matica hrvatska, Zagreb 2017., str. 109-129.

20

Usp. F. W. J. Schelling, »Filozofijska istraživanja o bitstvu čovječje slobode i predmetima koji su s time u svezi«, str. 26 i d./27 i d.; SW VII, $354 \mathrm{i}$ d.

21

Ibid., str. 30; SW VII, 357.

22

Ibid., str. 31; SW VII, 358 i d.

23

Ibid., str. 32; SW VII, 360 i d. 
volje dodaje nešto inteligibilno, tj. Božje ideje koje predstavljaju Riječ; ili točnije: ukoliko se on pod utjecajem stvaralačke Božje ljubavi razvija prema inteligibilnosti (umstvenosti) kako je to opisano u filozofiji prirode.

»Svako bitstvo (Wesen) koje je nastalo u prirodi na pokazani način ima u sebi dvostruk princip koji je ipak u temelju samo jedan te isti, promatran s obje moguće strane. Prvi princip je ono putem čega su bitstva odijeljena od Boga, ili putem čega su ona u pukom temelju; no budući da se između onoga što je predobrazovano u temelju, i onoga što je predobrazovano u razumu, nahodi ipak jedno izvorno jedinstvo, a proces stvaranja smjera samo na unutrašnju transmutaciju ili preobraženje prvobitno mračnoga principa u svjetlo (jer razum ili svjetlo postavljeno u prirodu u temelju zapravo traži samo njemu srodno, prema unutra okrenuto svjetlo): to je onaj po svojoj prirodi mračni princip upravo taj koji se istodobno preobražava u svjetlo, i oba su, iako samo u određenom stupnju, jedno u svakom prirodnom bitstvu. Princip, ukoliko on potječe iz temelja i ukoliko je mračan, jest svojevolja kreature, (...) puka hlepnja ili požuda, to jest slijepa volja. Ovoj svojevolji kreature stoji razum nasuprot kao univerzalna volja, koja onu upotrebljava i sebi podređuje kao puko oruđe. (...) U svim stvarima jesu doduše oba principa, ali bez potpune konsonancije uslijed nedostatnosti onoga što je uzdignuto iz temelja. Tek u čovjeku biva (...) potpuno izgovorena Riječ koja je u svim ostalim stvarima još suzdržana i nepotpuna. Ali u izgovorenoj Riječi objavljuje se duh, to znači Bog kao actu egzistirajući. ${ }^{24}$

Nema, međutim, općenito u stvorenjima savršene istovjetnosti obaju počela, a nema je ni u čovjeku. Kad bi bila savršena istovjetnost, ne bi bilo nikakve razlike između čovjeka i Boga, tj. Bog se ne bi objavio prema van - a ta se objava traži da bi Bog bio ljubav i duh. Odatle slijedi mogućnost dobra i zla odnosno ambivalentnost ljudske volje ukoliko imamo ili savršenu usuglašenost vlastite volje (koja proizlazi iz prirodnog ne-božanskog kaotičnog počela) s univerzalnom voljom (koja djeluje u skladu s umskim božanskim počelom), ili pak afirmaciju vlastite volje i egzistencije kao od Boga odijeljene.

»Ako bi (...) u duhu čovjeka identitet obaju principa bio isto tako nerazriješiv kao u Bogu, onda ne bi bilo nikakove razlike, to jest Bog kao duh ne bi bio objavljen. Ono jedinstvo koje je u Bogu nerazlučivo, mora dakle u čovjeku biti razlučivo - i to je mogućnost Dobra i Zla. «25

Zbiljnost zla jest afirmacija vlastite volje; ona je nužno izazvana u stvorenom biću stoga što je u njemu također onaj mračni temelj koji potiče svoju vlastitu autonomiju. Štoviše, traži se da bude zlo zbiljsko kako bi se čovjek razlikovao od Boga (drugačije bi se on po toj savršenoj istovjetnosti obaju počela poistovjetio s Bogom) da bi se tako Bog mogao objaviti u nekoj drugosti, odnosno da bi se mogla ostvariti ljubav kao pobjednica nad zlom.

»Volja ljubavi i volja temelja jesu dvije različite volje, od kojih je svaka za sebe; ali volja ljubavi ne može odoljeti volji temelja, niti je može ukinuti, jer bi se inače morala opirati sebi samoj. Jer temelj mora djelovati, eda bi ljubav mogla biti, i on mora djelovati neovisno o njoj, da bi ona realno egzistirala. Ako bi sad ljubav htjela slomiti volju temelja, ona bi se borila protiv sebe same, bila bi u opreci sa samom sobom, i ne bi više bila ljubav. (...) Tako zacijelo volja temelja ne može slomiti niti ljubav, niti pak ona to žudi, makar to često tako izgleda; jer ona mora, odvraćena od ljubavi, biti naročita i posebna volja, da bi se sad ljubav, kada ona ipak probije kroz nju kao svjetlo kroz tamu, pojavila u svojoj svemoći. Temelj je samo jedna volja za objavom, ali upravo, da bi ova bila, mora on izazvati vlastitost i opreku. Volja ljubavi i volja temelja bivaju dakle upravo kroz to jedno da su one odijeljene, i da od začetka svaka djeluje za sebe. Otuda volja temelja odmah u prvoj stvorbi subudi (mit erregt) svojevolju kreature, da bi, kada sad izađe duh kao volja ljubavi, ovaj našao nešto opiruće u čemu se on može ozbiljiti.« 26

Sav taj teogonijski i kozmogonijski proces s pravom može biti shvaćen na idealistički način kao pokušaj da se izlože (transcendentalni) uvjeti mogućnosti bitka bića i njegove spoznaje. Kao što je ranije filozofija identiteta tražila preko i iza Fichteova jastva onaj zadnji uvjet ili zadnji temelj mišljenja u apsolutnoj istovjetnosti subjekta i objekta koju označuje um kao takav, tako se i sada u filozofiji slobode kaže da je taj temelj neka originarna i tamna če- 
žnja, jer čovječji um reflektirajući samoga sebe ne može potpuno rasvijetliti tu težnju iz koje on sam proizlazi; stoga on zna za sebe kao za onoga koji se razlikuje od Apsoluta ili Boga koji je sam sebi potpuno svijetao, razgovijetan - on jest Svjetlo.

Schelling dakle pokazuje (protiv Hegela?) da čovječji duh i Božji duh ne rezultiraju jedan iz drugoga, nego se originarno (izvorno) razlikuju prema najprvo različitim mogućnostima povratka nad same sebe odnosno reflektiranja samih sebe. Usprkos tome čini se da se i jedan i drugi ipak zamišljaju univokno jer se Božjem duhu daje posve ista »psihološka« struktura kao i onom ljudskom.

Ostaje međutim poteškoća filozofije slobode koju treba tražiti u pojmu nužne objave Božje kroz alteritet, tj. kroz ono drugo što je od Boga različito (stvorenje, stvorba). Pojam nužne objave utemeljuje dijalektiku teogonijskog procesa i nužnost razlikovanja stvorenja od Boga te stoga i mogućnost i zbiljnost zla. Ovdje se pak krije temeljna poteškoća koja se razabire u tome da filozof u tom sustavu mišljenja a priori shvaća slobodnu Božju objavu (pa tako i stvaranje) kao nužnu. Na to upućuju slike iz okružja prirode koje Schelling rabi u spisu o slobodi: rođenje iz mraka na svjetlo, sjemenka stavljena u zemlju gdje umire u tami da bi se uzdiglo i razvilo svjetlosno obličje, čovjek koji se obrazuje u majčinu krilu. ${ }^{27}$ No već u svojim Stuttgartskim privatnim predavanjima (1810.) on rabi slike koje govore o slobodnom životu duha: volja koja se susteže (kontrahira) da bi se afirmirala, veličina slobodno prihvaćena poniženja, ljubav koja nadvladava egoizam itd. ${ }^{28}$ Slike iz okružja prirode ne pokazuju mogućnost nadvladavanja ideje nužnog kretanja Apsoluta u objavi, dok slike iz života duha upozoravaju na to da procesu samoobjavljivanja Apsoluta prethodi čin slobodne hotnje - dakle, samoobjava iz slobode. Nešto kasnije u filozofiji Razdoblja svijeta ta se sloboda Apsoluta udvostručuje s obzirom na proces njegove samoobjave kroz stvaranje: jedna je ona koja je imanentna tom procesu, dok ga druga transcendira i njime ravna, a da taj proces nema povratnog učinka na nju. ${ }^{29}$ Tu je također važna slika rađanja (Zeugung) koju susrećemo i u spisu o slobodi - »rađanje, to jest postavljanje nečeg samostalnog $\ll^{30}$ - jer ono je jedini prikladni način postavljanja slobode drugoga uz istodobno očuvanje vlastite slobode onoga koji postavlja drugu slobodu; riječ je o uspostavi međuovisnosti u neovisnosti obojih slobodnih, u Bogu odnos Oca i Sina pa posljedično i odnos Boga i čovjeka (Stvoritelj - stvor).

Sukcesivne verzije Razdoblja svijeta, koliko god ostale nedovršene, pokazuju otkriće apsolutnosti početka i osobnosti (Persönlichkeit) Boga: Bog slobodan sam u sebi u svojoj vječnoj samorođenosti svojom suverenom odlukom u procesu stvaranja efektivno postaje slobodan za drugo i za drugoga-slobodnoga (čovjek). Schelling razvija tu misao tako da na mjesto nesvjesne čežnje

24

Ibid., str. 33-34; SW VII, 362 i d.

25

Ibid.

26

Ibid., str. 41; SW VII, 375-376.

27

Usp. ibid., str. 32 i d.; SW VII, 360.

28

Usp. SW VII, 429 i d. (= Stuttgarter Privat-

vorlesungen)
29

Usp. X. Tilliette, Schelling. Une philosophie en devenir, I, str. 625 i d.

30

F. W. J. Schelling, »Filozofijska istraživanja o bitstvu čovječje slobode i predmetima koji su s time u svezi «, str. 23; SW VII, 346. Usp. opširno X. Tilliette, I, str. 612 i d. 
u Bogu stupa biblijski lik mudrosti (Mudre izreke, 8) koja se igra pred licem Stvoritelja. U svojim interpretacijama Schelling hoće doprijeti do vječne slobode Boga u njezinoj nedodirivosti, blještavilu i čistoći (Lauterkeit).

»On hoće postaviti ono po čemu je Bog Bog, neosvojivo bitstvo božanstva pod 'zamotuljkom' njegove egzistencije: zastiranje - raskrivanje, uvijanje - razvijanje, povlačenje - širenje, jednom riječju: objava. $\ll^{31}$

Biblijska tradicija dakle suočuje Schellinga sa zahtjevom da misli u funkciji neosvojive Božje slobode koja se očituje u rađanju Sina i u stvaranju svijeta. Taj Bog je Bog apsolutnog početka, on kao nepredmislivo (unvordenklich) egzistirajući prethodi ideji Boga.

Schelling shvaća povijest stvaranja kao objavu Božju te tako priprema materijal za ono što će nazvati pozitivnom filozofijom. On ne ide za tim da a priori deducira treba li se i kako Bog objaviti, nego je napor mišljenja usmjerio na to da shvati de facto danu Božju objavu (kroz razdoblja kozmogonije, povijesti religije pa sve do eshatologije). To znači da povijest religijske svijesti čovječanstva postupno dolazi u središte njegove fillozofske pozornosti. Religiozna je svijest povlašteni izraz (iskustvo) povijesnog života čovječjeg duha pa se religija ne svodi na odgajateljicu ćudoređa, nego je u svojoj mitološkoj »verziji zastrta forma manifestacije božanstva u povijesti.

U toj drugoj periodi svojeg stvaralaštva Schelling dakle shvaća objavu kao unutarbožansku komunikaciju i kao manifestaciju Boga kroz stvaranje svijeta u čijem je središtu slobodan čovjek - naslovnik moguće posebne objave Boga.

\section{III.}

Iz prethodno izloženog proizlazi da Boga valja misliti kao slobodnog sve dotle da uđe u zbiljski odnos s povijesnom sviješću ljudi - slobodni Bog u zbiljskom (ne samo pomišljenom zbiljskom) odnosu sa slobodnim čovjekom, tj. s individuumom i čovječanstvom. Ovdje Schelling počinje pojam objave shvaćati u užem smislu kao povijesni čin. Time se pak samim pojmom objave uvodi nova kritika racionalnosti, kako to Schelling ističe u uvodnom dijelu svojih berlinskih predavanja o filozofiji objave. ${ }^{32}$ Nova kritika racionalnosti obrađena je kroz odnos racionalne (negativne, kritičke) filozofije i pozitivne filozofije. To je novi kontekst u kojem treba razvidjeti značenje i funkciju pojma objave.

Negativna ili racionalna filozofija negativna je u trostrukom smislu. Najprije, ona se drži negativno (možda bolje) neutralno spram zbiljskog bića i spram egzistencije kao takve. Um u njoj misli što nešto jest, esenciju ili bît, ono što može biti - neovisno o tome egzistira li to ili ne; njemu je važan pojam koji izražava sadržaj, egzistencija toga njemu je od sporedne važnosti. »Okolnost postoji li to 'nešto' ili ne ni najmanje ne mijenja moj pojam sadržaja«, navodi Schelling Kanta te ističe da se negativna filozofija konstituira neovisno o iskustvu; veza s njim njoj je akcidentalna te ona napreduje po svojoj imanentnoj nužnosti. ${ }^{33}$ Nadalje, ona je negativna u tom smislu da se kreće postupno eliminirajući sve ono kontingentno, slučajno, idući za tim da u mišljenju dopre do bitka samog kao čistog čina. ${ }^{34}$ Njezina je pak kritička funkcija da razlučujući bîti ili potencije (tj. ono što može biti; razni modusi bića) dopre do bitka samog bez ikakve esencije, tj. do čistog biti ili do čistog »jest « (ili »da«, »dass «) koje je bez »što«. Ona dopire do toga - i to je treće - kao do temelja mislivosti, ali ona taj temelj ima na negativan način, kao pojam ili ideju - ali bez sadržaja. 
Drugim riječima, tako dugo dok um samog sebe čini predmetom nalazi on samo beskonačnu potenciju bitka kao svoj predmet; po tome um samog sebe poima u apriornom položaju spram sveg i svakog konačnog bivstvujućeg. U mišljenju toga um ide uvijek dalje. Radi se o mišljenju u kojem se misli »nešto« kao »nešto« pod vidikom svoje mogućnosti. To se misli po dijalektici reda esencija ili štostava i to pomoću negacijā. No promišljajući taj svoj način djelovanja um spoznaje da je manjkav i slab jer ne može do kraja iscrpsti svoj sadržaj, tu nema nekog kraja ili zaključka, nego um uvijek iznova otkriva i nalazi samog sebe kao već postavljeni temelj svoje spoznaje (to da on već jest), a da nikada ne može misliti drugo doli neki sadržaj, neko nešto. Kad um dakle istražuje i promišlja samog sebe, on se doista pokazuje autonomnim; no to nipošto ne znači da je nužno $d a$ postoji nešto takvo kao um. Ako um egzistira, on egzistira nužno. Ali to $d a$ on egzistira ponajmanje se ima zahvaliti njemu samom, pa odatle pitanje:

»Zašto uopće um jest, zašto nije ne-um?«35

Um je suočen s time da taj proces nema kraja - osim ako ne postavi zahtjev za onim što je nad svim bivstvujućim ono nadbivstvujuće (das Überseiende), za čistom egzistencijom ili čistim bitkom bez ikakvog »što«, bez ikakve bîti ili esencije kao predmeta mišljenja. Tom nadbivstvujućem ne prethodi nikakav pojam, nikakva esencija; mišljenje uma ne može mu naći nikakav temelj ili početak, ali niti nekakvo »što« kao predmet mišljenja.

Ovdje se zahtijeva ekstaza uma koja se sastoji u tome da se on odrekne svog uobičajenog kretanja, tj. imanentnog diskursa koji a priori proizvodi red esencija ili ideja, da bi se sada nepomičan usredotočio i kao u onom tuđem zastao u temelju svoje vlastite zbiljnosti, naime u čistom činu postojanja, u čistoj egzistenciji, u čistome bitku - da jest. Problem je ovdje kako misliti egzistenciju bez esencije, ono čisto biti bez ikakvog »što«. Ako je um sam sebi predmetom, ako se mišljenje usmjeruje na sadržaj uma, kao u negativnoj filozofiji, to je nešto akcidentalno, um time još ne misli samog sebe kao naprosto egzistirajućeg bez ikakvog »što«. Ako on to čini, ako se ne povlači u samoga sebe tražeći u sebi neki sadržaj, neko »što«, nego ustraje u motrenju čistog čina onog biti, onda je on samom sebi transparentan

»... kao beskonačna potencija spoznavanja kojoj može odgovarati samo beskonačni čin (Actus). U skladu sa svojom pukom naravi um postavlja ono beskonačno bivstvujuće samo; no obrnuto gledano um je u postavljanju istoga kao nepokretan, kao ukočen, quasi attonita [kao zapanjen]. $\ll^{36}$

31

X. Tilliette I, str. 613; usp. također SW XIII, 294 i d.

32

Usp. SW XIII, 1-173 (= Philosophie der Offenbarung); X. Tilliette II, str. 37-66.

33

SW XIII, 65-66.

34

Schelling rabi pritom razne nazive: Actus, Prius, das Überseiende, das blosse Sein/Seiende čija se značenja za njega poklapaju.

35

SW XIII, 247.
36

SW XIII, 165; ovdje Schelling podvrgava kritici Kantovu kritiku kozmološkog dokaza za Božje postojanje. Usp. X. Tilliette II, str. 49. Korisno je ovdje upozoriti na još nešto: iz toga da stvari u mišljenju (esencije) tvore skup kojim vlada nužnost u skladu s načelom proturječja nipošto ne slijedi da one egzistiraju nužno. Um naime može pitati: »warum ist überhaupt etwas? warum ist nicht nichts? - zašto je uopće nešto? zašto nije ništa? « (SW XIII, 6). To pitanje nameće umu šutnju i pokazuje da egzistencija ne samo onog pojedinačnog faktičnog nego i egzistencija cjeline svega egzistirajućeg kao takvog (stvorenje) izmiče zahvatu uma; »da« prethodi onomu »što« (usp. SW VII, 85 i 80; Tilliette II, str. 46). 
Um dopire dakle sve do temelja svake mislivosti, naime do promatranja čistoga čina onog biti.

Schelling kaže isto, ali na drugi način, polazeći od ideje beskonačnog bivstvujućeg:

»Ono naprosto bivstvujuće (bloss Seyende) jest bitak u kojem je isključena svaka ideja, tj. potencija. Moći ćemo ga dakle zvati samo obrnutom idejom, idejom u kojoj je um postavljen izvan sebe. Um može ono bivstvujuće, u kojem još nema ništa od nekog pojma, od nekog »što « (Was), postaviti samo kao apsolutno izvan-sebe (...) stoga je um u tom postavljanju postavljen izvan sebe, on je apsolutno ekstatičan. « 37

Tu se otkriva da mišljenje uma ovisi o bitku koji nije mišljenje, nego je apsolutni prius svemu što je mišljeno i može biti mišljeno, apsolutni prius svemu što jest i može biti - i apsolutni prius samome umu. Taj čisti bitak ili čista egzistencija umu je unvordenklich, apsolutno prethodna, ne-pred-misliva: nema ničeg što bi bilo i moglo biti i mislilo se prije njega, on svemu prethodi kao ono apsolutno jestvujuće prije svakog bića i mišljenja.

U izrazu unvordenklich valja čuti dvoje: ono koje je ne-pred-mislivo ujedno je i ne-mislivo jer tu nema nekog »što « (esencija, bît) kao sadržaja mišljenja. Schelling ipak ne odbacuje taj izraz jer je on za njega razlogom da se promijeni smjer mišljenja - što se ne mora, ali se može ako se hoće. Negativnom mišljenju (negativna filozofija) koje se bavi onim što je a priori shvatljivo Schelling stavlja uz bok (nipošto protiv njega!) pozitivno mišljenje; ovo se bavi onim ne-pred-mislivim, a priori neshvatljivim, radi toga da ga »a posteriori preobrazi u ono shvatljivo«. Anticipirajući ono što slijedi možemo reći: Unvordenklichkeit, ne-pred-mislivost čiste egzistencije početak je Schellingove pozitivne filozofije. ${ }^{38}$

Umjesno je pitati se zašto je um zapanjen, ukočen, nepokretan pred čistim činom onog biti. Schelling kaže:

»Um se ukrutio pred bitkom koji svime vlada samo da bi po tom podvrgavanju prispio svojem pravom i vječnom sadržaju - on ga ne može naći u osjetilnom svijetu - kao onom zbiljski spoznatom koji on sada i stoga vječno posjeduje. $\ll^{39}$

Tu je u središtu pozornosti obrat od negativne k pozitivnoj filozofiji. ${ }^{40}$ Negativna filozofija polazi od onog što je prije iskustva ili što je iza bića - pojam koji znači esenciju, bît bića. Pozitivna filozofija polazi od onog što je iznad bića $\mathrm{i}$ iskustva, tj. od onog što je nadempirijsko, što nadilazi iskustvo. To je apsolutni prius, dok je prius negativne filozofije relativni prius. Pozitivna filozofija ide od apsolutnog prius-a prema iskustvu. Obje te filozofije imaju dakle posla s iskustvom, ali na obrnut način. Stavovi negativne filozofije počivaju na pretpostavci: ako postoji svijet, onda ga spoznajemo kako je to npr. Kant prikazao. Stavovi pak pozitivne filozofije počivaju na htijenju kojem ništa ne prethodi: ako apsolutni prius hoće, tad postoji itd. U negativnoj filozofiji iskustvo ima potvrđujuću funkciju, dok je njegova funkcija u pozitivnoj dokazna i pokazna (erweisend, nachweisend). Pozitivna filozofija naime dokazuje prius per posterius. ${ }^{41} \mathrm{U}$ pogledu svijeta pozitivna filozofija je apriorna znanost koja se izvodi iz apsolutnog prius-a čistog bitka; u pogledu Boga pak ona je aposteriorna znanost i spoznaja jer iskustveni moment igra presudnu ulogu u dokaznom postupku:

»Ne treba biti dokazan apsolutni prius sam (to je iznad svakog dokaza, to je apsolutan, sam po sebi izvjestan početak), dakle ne on sam (tj. apsolutni prius) treba biti dokazan, nego ono što slijedi (die Folge) iz njega: posljedica mora biti faktično dokazana pa time i božanstvo onog prius - da je on Bog i da Bog dakle postoji. Reći ćemo dakle: prius, čiji je pojam ovo i ovo (pojam nadbivstvujućeg), moći će imati takvu posljedicu (nećemo reći: nužno će imati takvu posljedicu, jer u tom bismo slučaju upali natrag u nužno, tj. po pukom pojmu određeno kretanje; smjet ćemo 
reći samo ovo: prius može imati takvu posljedicu ako on to hoće; posljedica je ovisna o njegovoj volji). Sad pak zbiljski egzistira ta posljedica (ova rečenica počiva na iskustvu; egzistencija takve posljedice jest factum, činjenica iskustva). Dakle, taj nam factum pokazuje - egzistencija takve posljedice pokazuje nam da i sam prius tako egzistira kako smo ga mi shvatili, tj. da Bog egzistira. (...) Prius je spoznat iz svoje posljedice, ali on nije tako spoznat da bi mu ta posljedica prethodila. $\ll^{42}$

Ovdje nije dokazan apsolutni prius (čisti čin onog biti, čista egzistencija, ono nadbivstvujuće itd.) jer je on već otkriven u regresivnom postupku negativne filozofije; ovdje je dokazano njegovo boštvo pa prema tome i stvorenje. Pozitivna filozofija ne polazi od pojma Boga, ona ne polazi ni od kakvog pojma nego od onoga što prethodi svemu mišljenju i ponad je svake misli: prius koji se ne da zbiti u pojam, ono nužno egzistirajuće, ne-pred-mišljeni (unvordenklich) bitak sam. To je početak mišljenja i misli - pa se pozitivna filozofija okreće mišljenju i pojmu, misli apsolutni prius u njegovim posljedicama te ga čini predmetom mišljenja -

»... po cijenu preobrazbe i proširenja filozofije. U pozitivnoj filozofiji onaj ne-pred-mislivi a priori postaje Bog pojmljen a posteriori. Bog nije dakle ni transcendentni ni imanentni: on je transcendentni koji je postao imanentnim. $\ll^{43}$

U pozitivnoj filozofiji ne misli se dakle sam bitak (ono $d a$ jestvujućega), nego bića (jestvujuća, ono što) - ali ne u uobičajenom smislu, nego u drugom smislu, naime kao uprisutnjenja samoga bitka.

»Premda smo se služili principima bitka (kako smo ih nazvali) kao stepenicama i prečkama da bismo došli do njega, ipak smo na kraju bili prisiljeni shvatiti da su ti principi bili koraci samo za nas te i samo s propedeutičkom (didaktičnom) svrhom; ako se pak promatra objektivno, sa stajališta onog samog duha, odnos se preokreće pa su ti principi radije posljedica, oni su ono potonje (Posterius) duha. Dakle apsolutni duh može doduše biti dokazan po tim principima, ali on to ne može biti po njima kao po svojem prius, nego samo kao po svojem posterius; to znači da on može biti dokazan samo a posteriori. $\ll^{44}$

U dokaznom postupku (koji nije ovdje tema) pokazano je da se Bog odnosi ne samo spram bića u ideji nego i spram bića izvan ideje (empirijsko egzistirajuće biće) pa je on uzrokom jednog i drugog. Time je pokazana njegova zbiljnost neovisno o ideji - zbiljnost čak i kad bi se ukinula ideja. To znači: Bog se objavljuje kao Gospodar bitka (Herr des Seyns). ${ }^{45}$ On je Stvoritelj.

Još jednom, ali drugim riječima, u racionalnoj znanosti (negativna filozofija) um intuira Boga kao ono zadnje do čega on može doprijeti - i tu zastaje, ukočen. Um ima ovdje samo idealan odnos spram Boga (Bog-ideja) i ne može

37

\section{SW XIII, 162 i d.}

38

Ibid., 165; »Das a priori Unbegreifliche wird in Gott ein Begreifliches « (isto mj.). Detaljnije izvode o tome usp. u prvom dodatku filozofiji objave u SW XIV, 338-356, napose 335-345, pod naslovom »Andere Deduktion der Principien der positiven Philosophie«. O terminu unvordenklich usp. također Tilliette I, str. 598 i d. te 638 nap. 30 gdje se upućuje na taj izraz kao prijevod gr. anypótheton i II, str. 363-364 (fr. prijevod: immémorial).

39

SW XIII, 165.

40

O ovome što slijedi usp. Tilliette II, str. $49 \mathrm{i}$ d.
41

Ovo »a« u izrazu a posteriori Schelling ne shvaća kao terminus a quo; »a posteriori znači ovdje per posterius, [apsolutni] prius je spoznat po onom ili kroz ono (durch) što iz njega slijedi «. - SW XIII, 129.

42

Usp. SW XIII, 129 i d.

43

Tilliette II, str. 51.

44

SW XIII, 248 i d.

45

Usp. SW XIII, 93 i 160. O dokazivanju usp. SW XIII, 148-174. 
imati neki drugi odnos jer racionalna znanost vodi do Boga »samo ukoliko je on causa finalis, a ne vodi k tomu što Bog zbiljski jest [nicht zu dem was wirklich Gott ist]; ona vodi samo k nečemu što je po svojoj esenciji Bog, ali ne i do zbiljskog Boga «. ${ }^{46}$ Stoga se ovdje zahtijeva obrat mišljenja ako se želi ići dalje, ne preko racionalne znanosti nego radije uz nju, k zbiljskome Bogu. Taj obrat mišljenja nije nuždan i ne može proizići iz pukog mišljenja. Za njega je potreban »praktičan podstrek «; ${ }^{47}$ u mišljenju pak nema ničeg praktičnog, ono se bavi pojmovima i njihovim nužnim relacijama, dok je ovdje riječ o nečemu koje je izvan nužnosti i koje može biti izvedeno samo iz slobode. Volja jastva (Ich) ovdje je ona koja zahtijeva »da Bog ne bude samo pukom idejom « nego zbiljski Bog: »Bog koji djeluje, koji proviđa, Bog koji de facto postoji, koji djelatno može izliječiti pogreške, riječju: Bog koji je Gospodar bitka [Herr des Seyns]《. Budući da »osoba traži osobu«, jastvo »može htjeti Boga i nadati mu se da po njemu postane dionikom blaženstva « koje neće biti »blaženstvo što ga valja steći po zasluzi pa stoga ni razmjerno (kao što je htio Kant), već samo nezasluženo blaženstvo pa stoga i neproračunljivo i preobilno«. Schelling ističe da »to htijenje Boga nije kontingentno«, čovječjem duhu ravnodušno. Naprotiv, »ono je htijenje samog duha koji po svojoj unutrašnjoj nužnosti i radi želje za svojim oslobođenjem ne može zastati u onome što je sadržano u mišljenju. Kao što taj zahtjev ne može proizići iz mišljenja, tako on nije ni neki postulat praktičnog uma. Ne vodi k Bogu praktični um (kao što je htio Kant), nego samo individuum. U čovjeku ne želi blaženstvo ono što je univerzalno ili opće, nego individuum«.

Svrha je pozitivne filozofije pokazati to i dovesti do tog cilja. Apsolut se - prema svemu izloženome - ne objavljuje u diskursu razuma, nego samo u zbiljskom životu duha; on postaje predmetom mišljenja u obratu samog mišljenja pa se Schelling okreće promatranju zbiljskog života duha u ljudskoj povijesti i tumači taj život duha kao objavu Apsoluta. Drugim riječima, um svjestan svoje faktičnosti, u obratu se vraća natrag k svojoj pretpovijesti u mitu i u kršćanskoj objavi. Zato pozitivna filozofija uzima u razmatranje mitologiju i kršćanstvo kao objavljenu religiju i u njima »čita« zbiljski život duha i prisutnost zbiljskog Boga koji se povijesno manifestira, tj. samog sebe objavljuje onom drugom slobodnom, čovjeku odnosno ljudskome rodu.

Najprije u mitopojezi, tj. u mitovima, ljudski je duh od početka povijesti čovječanstva izražavao svoju vlastitu zbiljnost kao zbiljski usmjerenu prema Bogu; tako je on konstituirao prirodnu religiju, temelj svake religije koja se nikad ne bi mogla utemeljiti u razumu. Gledana u perspektivi kršćanske objave Filozofija mitologije pokazuje se kao put prema Kristu, neka vrsta uzlazne »kristogonije« (nastajanja Krista) koja se dovršuje u noći Božića ${ }^{48}$ kojoj su prethodile noći grčkih misterija (i tek nešto malo starozavjetno religiozno iskustvo!) i starog svijeta i njegovog dubokog tragičnog osjećaja neprevladive konačnosti postojanja. ${ }^{49}$

Definitivno se pak sebeobjavljivanje Boga događa u kršćanskoj objavi; u njoj se preobrazuje mitopoetski realni odnos prema Bogu (prirodni i neizbježni, tj. nevoljni proces), u odnos koji je izričito htijen te stoga i slobodan, kako sa strane Boga tako i sa strane čovjeka. Tu se pretpostavlja temeljna i čovjeku nepremostiva razlika između njega i Boga pa stoga »pojam objave pretpostavlja neko praiskonsko zamračenje (ursprüngliche Verdunkelung). Bog se može objaviti samo provaljujući u to zamračenje «. ${ }^{50}$ Schelling odbacuje ideju praobjave Božje (Uroffenbarung) jer bi ona značila da je čovječja svijest izvorno bez-božna pa bi joj se Bog morao objaviti pred-povijesno, tj. na samom početku postojanja ljudske vrste. ${ }^{51}$ Kršćanska objava pak je povijesni čin koji se uzdiže u noći mi- 
tologije kao slobodan čin u vremenu i kao nečuven odgovor agoniji mitološke svijesti $^{52}$ svojom porukom o uskrsnuću, uspostavom prisne relacije s Bogom u vremenu $^{53}$ te otvaranjem nove duhovne budućnosti čovječanstvu. ${ }^{54}$ To se otkriva - objavljuje! - u evanđelju: ono nije doktrina, nego je naracija Kristovih djela i činjenica vezanih uz njegovu osobu. On, Krist, sadržaj je kršćanske objave pa se filozofija objave koncentrira u filozofskoj kristologiji. U svemu tome je vidljivo: objavu je moguće shvatiti samo kao događanje iz slobode za slobodu. Schellingova Filozofija objave pokazuje se dakle kao misao koja propituje smisao i doseg kršćanske objave kao povijesne činjenice za religioznu svijest čovječanstva. Ta je svijest otuđena, smatra Schelling, time što odbija povezati svu stvarnost s izvornom ljubavlju. ${ }^{55}$ Zbog tog odbijanja ona oduvijek luta u izvanjskosti, ali je principijelno obnovljena i stavljena u svoju punu istinu po Kristu. To što je tako dano po objavi nije neki vanjski svijet koji povijesni čovjek mora sebi neposredno pretpostaviti i svoj život shvatiti kao proces posredovanja samoga sebe s tim svijetom, nego je to unutarnji svijet čiji princip (objava u Kristu) on doduše nije prisiljen prihvatiti - on je slobodan - ali si ga u pre-okretu mišljenja i u slobodi »može prisvojiti samo ukoliko za to ima srca, ukoliko ima odvažnosti prihvatiti objavu kao zbiljsku «. ${ }^{56}$ Objavom u Kristu principijelno je inauguriran povijesni proces interiorizacije evanđelja - vrijeme Crkve čiji završni model Schelling nazire u Ivanovu evanđelju. ${ }^{57}$

Schelling je uvjeren da je time razvio onaj sistem koji je »dovoljno jak da izdrži probu života i koji prevladava sve uskoće dotadašnje teologije i filozofije. Tomu je tako stoga što filozofija objave nije sistem nužnosti, nego slobode pa ona postiže ono »povrh čega nema više ničeg višeg «. ${ }^{58}$

46

SW XI, 560 (= Philosophie der Mythologie I: Darlegung der rein rationalen Philosophie).

47

SW XI, 565-569, str. 565; citati koji slijede preuzeti su odavde.

48

Schelling piše u SW XIII, 529 i d.: »Ne u buci, ne u divljem omamnom zraku bakantskih povorkā [nego] u tišini onih ozbiljnih noći u kojima si je Grk postao svjestan $s$ nužnošću ujedno i prolazne stvarnosti, tj. prolaznosti mitoloških predodžaba - a iz duboke noći koja sve obavija probilo se novo čudesno svjetlo -, u tišini tih noći i u ozbiljnosti njihovih misli ležalo je pomirenje mitologije koliko je ono bilo moguće unutar nje same.« - isto u UphO, 389 (kurziv SK).

49

U okviru ovog rada ne možemo ulaziti u prikaz filozofije mitologije; usp. o toj temi Tilliette II, str. $393 \mathrm{i}$ d.

50

UphO, 10; isto u SW XIII, $187 \mathrm{i} \mathrm{d}$.

51

Usp. SW XI, 180 i d.

52

Usp. SW XI, 141; XIII, 219.

53

Usp. SW XIV, 79 i 169.
54

Usp. SW XIV, 254, 263, 272.

55

Usp. SW XIII, 360.

56

Usp. UphO, 426.

57

Usp. SW XIV, 332. O ivanovskoj Crkvi koja tek treba doći (nakon petrinske i pavlovske) usp. SW XIV, 331 i d.; za cijelu filozofsku ekleziologiju usp. 294-334; također Tilliette II, str. 354 i 444.

58

UphO, 3 i 78. S obzirom na odnos spram teologije usp. Albert Franz, »Schellings Philosophie der Offenbarung und die Theologie«, Philosophisches Jahrbuch 104 (1997) 1, str. 373-389; Malte D. Krüger, »Verborgene Verborgenheit« u: Markus Mühling, Martin Wendte (ur.), Entzogenheit in Gott. Beiträge zur Rede von der Verborgenheit der Trinität, Ars Disputandi, Utrecht 2005., str. 125-159. Već ranije: Walter Kasper, Das Absolute in der Geschichte: Philosophie und Theologie der Geschichte in der Spätphilosophie Schellings, Matthias-Grünewald-Verlag, Mainz 1965. Opširan prikaz pozitivne filozofije daje Tilliette II, str. 343-488, posebice pak filozofije kršćanstva na str. $435 \mathrm{i}$ d. 
Pojam objave u Schellingovoj filozofiji kršćanskog je podrijetla, ali ga Schelling uzima u vrlo širokom smislu kao »materiju« koja mu je zadana u čovječjem povijesnom iskustvu i koja je prisutna u filozofskoj misli. Kao takva ona je slobodna tema filozofije, a Schelling joj daje veoma široko značenje: njome se signalizira spoznajno otkrivanje bezuvjetnosti i autonomije čovječje slobode povezano sa shvaćanjem kršćanske objave kao odgajatelja čovječanstva. Postupno međutim sve više pojam objave zauzima važno mjesto u Schellingovu filozofskom naporu koji ide za tim da podastre umnu eksplikaciju i utemeljenje Apsoluta kao onog koje je pred-umno, umu onostrano, a da u toj eksplikaciji nije svedeno na imanenciju koja je vlastita umu i njegovu umovanju. Pojam objave time signalizira slobodu Apsoluta i njegova djelovanja, napose pak njegova djelovanja u povijesti religiozne svijesti koja kulminira u kršćanskoj objavi, točnije u Kristovoj osobi. Time Schellingova pozitivna filozofija, posebice filozofija objave, ne postaje zakrabuljenom teologijom; ona je u prvom redu filozofija kršćanske religije, filozofija koja promišlja također smisao i razloge slobodne religiozne opcije za egzistenciju a da pritom nije sputana ni teološkim ni religijsko-kritičkim interesima.

\section{Stjepan Kušar}

\section{Offenbarung in der Philosophie?}

\section{Ein Einblick in den Begriff der Offenbarung in Schellings Philosophie}

\section{Zusammenfassung}

Im Artikel werden die tragenden Konturen des Offenbarungsbegriffs im Denken Schellings hervorgehoben. Der Begriff hat den christlichen Hintergrund, wird aber von Schelling nicht auf konfessionelle Ebene festgelegt oder reduziert. Schelling nimmt ihn als Realität in der geschichtlichen Erfahrung der Menschheit; als solcher ist er interessant für die Philosophie. Das Thema der Offenbarung markiert bereits die erste Periode des Schellingschen Denkens: mit ihm wird die erkenntnismässige Entdeckung der Unbedingtheit und Autonomie der menschlichen Freiheit verbunden und zwar im Zusammenhang mit dem deutsch-aufklärerischen Verständnis der christlichen Religion als Erzieherin des Menschengeschlechts in moralibus. In der zweiten Periode, die man mit Schellings Freiheitsschrift beginnen und mit den Weltaltern fortsetzen lässt, wird der Offenbarungsbegriff im Zusammenhang mit der Problematik des Bösen, der Freiheit und der Schöpfung behandelt. Er signalisiert die Freiheit des Absoluten und seiner schöpferischen Wirkung und Präsenz in Natur und (Religions)Geschichte der Menschheit - allerdings wird das Böse als notwendiges Moment der Offenbarung verstanden. In der letzten Periode seines Denkens (Philosophie der Mythologie und der Offenbarung) behandelt Schelling die Offenbarung (vor allem Offenbarung in Christo) als freie geschichtliche Manifestation des Absoluten, die zugleich als Angebot und Apel an seine freie Annahme von Seiten des Menschen verstanden und dargestellt wird. Die positive Philosophie Schellings ist keineswegs eine verkappte christliche Theologie; mit einem gewissen Recht könnte man sie vielleicht als Philosophie der christlichen Religion nennen. Ihr geht es darum, die Inhalte der christlichen Religion durchzudenken, ohne damit den Interessen der Kirchen Dienst in ihren Anliegen erweisen zu wollen, aber auch ohne mit den Interessen der Religionskritik gehemmt zu sein. Die Philosophie der Offenbarung versucht Leben und Wirken Gottes zu beschreiben, der seiner Schöpfung zuvorkommt und sie zur Vollendung zu führen beabsichtigt - auf dass Gott alles in allem wird.

\section{Schlüsselwörter}

Friedrich Wilhelm Joseph Schelling, Offenbarung, Religion, Freiheit, Absolutes, negative und positive Philosophie, Gott, Christus 